\title{
Carboxymethylcellulase Production by Verticillium albo-atrum
}

\author{
By P. WHIT NEY, J. M. CHAPMAN AND J. B. HEALE \\ Department of Biology, Queen Elizabeth College, University of London, \\ Campden Hill, London, W. 8
}

(Accepted for publication 27 January 1969)

\begin{abstract}
SUMMARY
A strain of Verticillium albo-atrum produced CM cellulase in liquid culture containing either cellulose powder or carboxymethyl-cellulose (CM cellulose) as sole carbon source, and when the fungus was growing in its natural host (lucerne). The CM cellulase liberated when the fungus was grown in liquid culture was fractionated on Sephadex $\mathrm{G}_{75}$, giving three major peaks and two minor peaks of cellulase activity. The materials of the three major peaks differed from each other in molecular weight, Michaelis constant and $\mathrm{pH} /$ activity curve, but were the same whether induced by cellulose powder or CM cellulose. Incubation of the materials of the three major peaks with $\mathbf{C M}$ cellulose resulted in the production of only medium-length polymers and cellobiose. No cellobiase was detected in liquid culture. CM cellulase activity was found to be only slight in the living infected lucerne tissue but was considerable in the dead infected tissue.
\end{abstract}

\section{INTRODUCTION}

The components involved in the enzymic breakdown of cellulose (cotton) by Trichoderma viride were separated by Selby \& Maitland (1967) into a carboxymethylcellulase (CM cellulase), a cellobiase and a component $\left(C_{1}\right)$ which had no action alone but operated synergistically with the other two components to convert cotton completely into water-soluble products. Previous investigations with Myrothecium verrucaria (Selby \& Maitland, 1965) had shown that this fungus produces three major cellulolytic components, one having $90 \%$ of the total CM cellulase activity, the other two being mainly responsible for the activity of the filtrates towards cotton. Recently cellulases have been separated from the culture medium of Penicillium notatum. The larger of the two peaks obtained on DEA Sephadex A25 was further resolved into two components by fractionation on Sephadex G-75 (Pettesson, 1968).

The active role of cellulases during the penetration of plant pathogenic fungi through the cellulose walls of host tissues is in doubt. Talboys (I958) clearly demonstrated cellulase activity in cultures of Verticillium albo-atrum causing a vascular wilt disease in hops. Enzyme activity in cultures grown on filter-paper pulp led to the production of a reducing sugar, tentatively identified as cellobiose. Starch, sucrose, glucose and lactose were found to inhibit methylcellulase activity in the presence of cellulose, and from the likely presence of these substances in the host cells Talboys assumed that the passage of the very fine penetration hyphae through cell walls was accomplished by mechanical rather than by chemical means. He suggested that the cellulase system of $V$. albo-atrum involved both an initial cellulase (C I) and a CM 
cellulase (Cx), although no attempt at separation was made. Stoddart \& Carr (1966) found that the major wilting activity in $V$. albo-atrum filtrates could be ascribed to a high molecular weight fraction of protein and polysaccharide components, and since Selby \& Maitland ( 1967 ) found that the $\mathrm{Cr}$ component in Trichoderma cultures was a glycoprotein, it seems that protein-carbohydrate complexes are of considerable importance in the extra-cellular products of these fungi. In the present paper we report on the results of an investigation into $\mathrm{CM}$ cellulase produced by a strain of $V$. albo-atrum which attacks lucerne.

\section{METHODS}

Cultures. A strain of Verticillium albo-atrum isolated from diseased lucerne (from Norfolk in 1964) was cultured in $16 \mathrm{oz}$. medical flats containing $100 \mathrm{ml}$. of medium at $25^{\circ}$ in the dark for 20 days. The medium contained either cellulose powder (Whatman no. I) 5.0 g./1., or carboxymethylcellulose (CM cellulose) $\left(\mathrm{Na}^{+}\right.$salt, D.s. 0.45 to 0.55 , British Drug Houses), $5.0 \mathrm{~g} . / 1$., and the following mineral salts: $\mathrm{KCl}, 0.5 \mathrm{~g} . / 1$; $\mathrm{MgSO}_{4} 7 \mathrm{H}_{2} \mathrm{O}$, 0.5 g./1.; $\mathrm{FeSO}_{4} 7 \mathrm{H}_{2} \mathrm{O}$, 0.0I g./1.; in 0.05 M-sodium phosphate buffer $(\mathrm{pH} \mathrm{6.0)}$. The fungus was removed by centrifugation at $3000 \mathrm{~g}$ for $15 \mathrm{~min}$. in a swing bucket centrifuge. The supernatant fluid was reduced to about $5 \%$ of its original volume in a rotary evaporator at $45^{\circ}$ and the concentrate sterilized by membrane filtration (Oxoid 'standard' grade) before separation and assay procedures.

Enzyme separation. Approximately $25 \mathrm{ml}$. of sterile concentrate of culture fluid were applied to a column $(95 \mathrm{~cm} . \times 2 \cdot 5 \mathrm{~cm}$.) of Sephadex G-75 (dry sieved particle size $<75 \mu$ ) contained in a water jacket at $25^{\circ}$. The column was eluted with a solution containing $\mathrm{NaCl}$ I00 mM, $\mathrm{Na}_{2} \mathrm{HPO}_{4} 3.3 \mathrm{mM}, \mathrm{NaH}_{2} \mathrm{PO}_{4} 6.7 \mathrm{~mm}$ (pH 6.5) (Selby \& Maitland, I965), at a rate of $12 \mathrm{ml}$./hr., and the eluate collected in $5 \mathrm{ml}$. fractions. The Sephadex column was calibrated by using blue dextran ( $\mathrm{MW} 2,000,000$ ), bovine serum albumin (MW 64,000), peroxidase (MW 45,000), cytochrome c (MW I2,000) and sucrose (MW 342). The blue dextran, bovine serum albumin and cytochrome $c$ were assayed by measuring the extinction at 625,230 and $4 \mathrm{I} 2 \mathrm{~m} \mu$, respectively, the peroxidase by the hydrogen peroxide/pyrogallol method (Polis \& Shmukler, 1953) and the sucrose estimated by total fructose (Bacon \& Tell, 1948).

Assay methods. Eluted fractions of the culture medium were assayed viscometrically in an Ostwald type viscometer (BS/IP/U size D) with $\mathrm{I} \mathrm{ml}$. samples and $25 \mathrm{ml}$. I \% carboxymethylcellulose (CM cellulose) $\left(\mathrm{Na}^{+}\right.$salt, D.S. 0.45 to 0.55 , B.D.H.; prepared by mechanical stirring at room temperature) in 6 mM-acetate buffer $\left(\mathrm{pH} 5^{\circ} \mathrm{o}\right)$. Reaction mixtures were incubated at $25^{\circ}$ for $30 \mathrm{~min}$.

Michaelis constants of the materials of the three main enzyme peaks, separated by the above method from cultures grown in media containing either cellulose powder or $\mathrm{CM}$ cellulose as the sole carbon source, were calculated from results of viscometric assays. The disappearance of substrate is expressed in CM cellulose equivalents, i.e. the concentration of CM cellulose that would have the same viscosity. The molecular weight of the $\mathrm{CM}$ cellulose used for $\mathrm{Km}$ determinations was calculated from osmotic pressure measurements with a high speed membrane osmometer (Mechrolab model 502 ) at $25^{\circ}$ with concentrations ranging from 0.01 to $0.07 \%$.

The effect of $\mathrm{pH}$ value on the activity of the three main enzyme components was investigated viscometrically by using $2 \mathrm{ml}$. of $0.2 \mathrm{M}$-citrate phosphate buffer, $0.3 \mathrm{ml}$. 
enzyme solution and $25 \mathrm{ml}$. I \% CM cellulose. Results are expressed as a percentage of the maximum activity.

The long-term breakdown of CM cellulose by the three main components separated from cultures grown in a medium containing cellulose powder was followed viscometrically over a period of $\mathrm{I} 20 \mathrm{hr}$ (chloroform was added to maintain sterility). At the end of these incubations $5 \mathrm{ml}$. of each mixture was made up to $70 \%(\mathrm{v} / \mathrm{v})$ ethanol in water (to precipitate long-chain polymers) and then de-salted on a bio-deminrolit column (I $2 \mathrm{~cm} . \times 2 \mathrm{~cm}$.) (B.D.H. I965). The eluate was concentrated under infra-red lamps before paper chromatography. Chromatograms (Whatman no. I paper) were run for 20 to $24 \mathrm{hr}$ with solvent $n$-propanol + ethyl acetate + water ( $3+2+5$, by vol.). Carbohydrates were detected by spraying with trichloraceticacid + benzidine (2 g. trichloracetic acid $+0.24 \mathrm{~g}$. benzidine $+5 \mathrm{ml}$. water made up to $100 \mathrm{ml}$. with ethanol (Bacon \& Edelman, I95I).

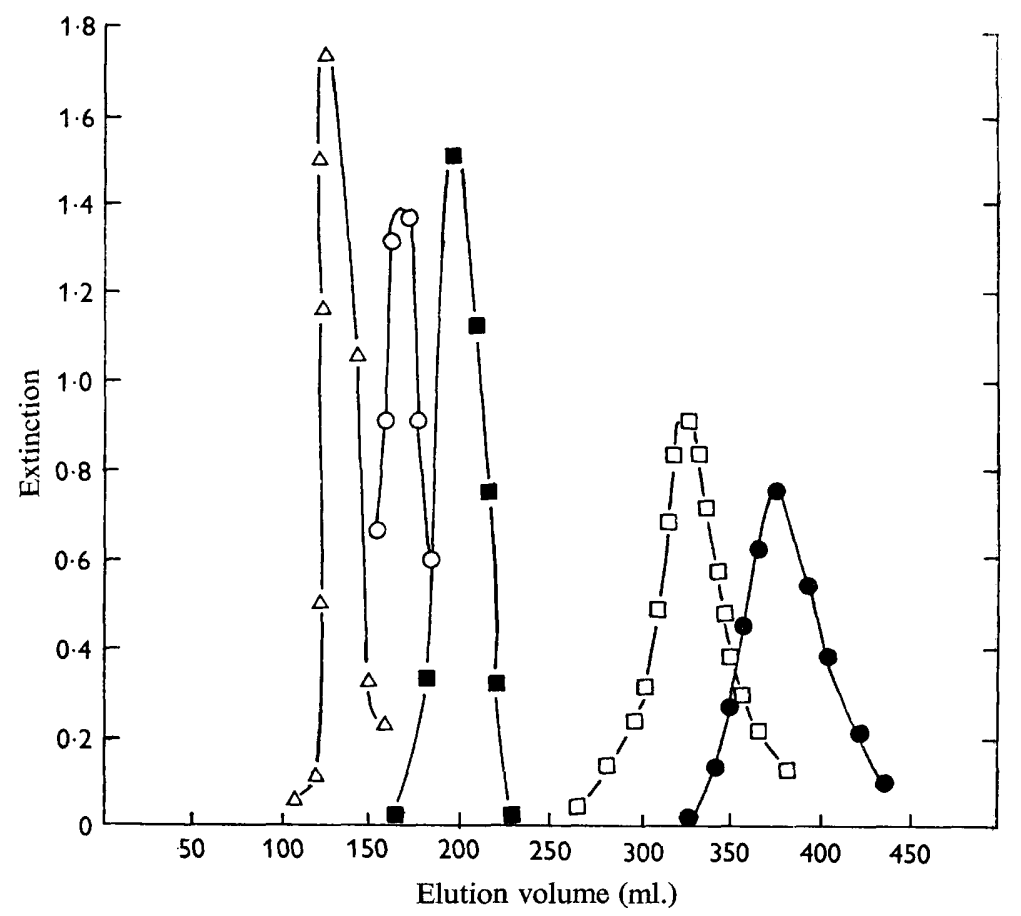

Fig. I. Elution pattern of standards from Sephadex G-75 column (showing volume of buffer required to elute standards of known molecular weight). $\triangle$, Blue dextran (M.W. $\left.2 \times 10^{6}\right) ; O$, serum albumin (M.W. $\left.6.4 \times 10^{4}\right) ; \square$ peroxidase (M.W. $\left.4.5 \times 10^{4}\right) ; \square$, cytochrome C (M.W. I $\left.2 \times 10^{4}\right) ; \bullet$, sucrose (M.W. 342 ).

Cellobiase activity was estimated (Nelson, 1944; Somogyi, 1952) by measuring the increase in reducing sugar after incubation of cellobiose solution with both the culture filtrate and the three separated CM cellulose peak components.

To investigate the production of $\mathrm{CM}$ cellulase in the host, tissue from various parts of healthy and diseased lucerne plants (Du Puit strain) was ground in O.I Mphosphate buffer ( $\mathrm{pH}_{5}{ }^{\circ} \mathrm{0} ; 0.5 \mathrm{~g}$. tissue $/ \mathrm{ml}$. buffer). The slurry was centrifuged at $3000 \mathrm{~g}$ for Io min. and I $\mathrm{ml}$. of the supernatant fluid assayed viscometrically for CM cellulase activity. The assay was done twice with different samples of lucerne material. 


\section{RESULTS}

In the Sephadex column calibration (Fig. I) the blue dextran indicates the void volume since it is totally excluded from the gel because of its high molecular weight $\left(2 \times 10^{6}\right)$. The sucrose was below the lower limit of separation obtainable with G-75, but the other three substances were clearly resolved. The molecular weight estimations based on the physical characteristics of the column (Whitaker, 1963) showed good correlation with the known weights of the standards (Fig. 2).

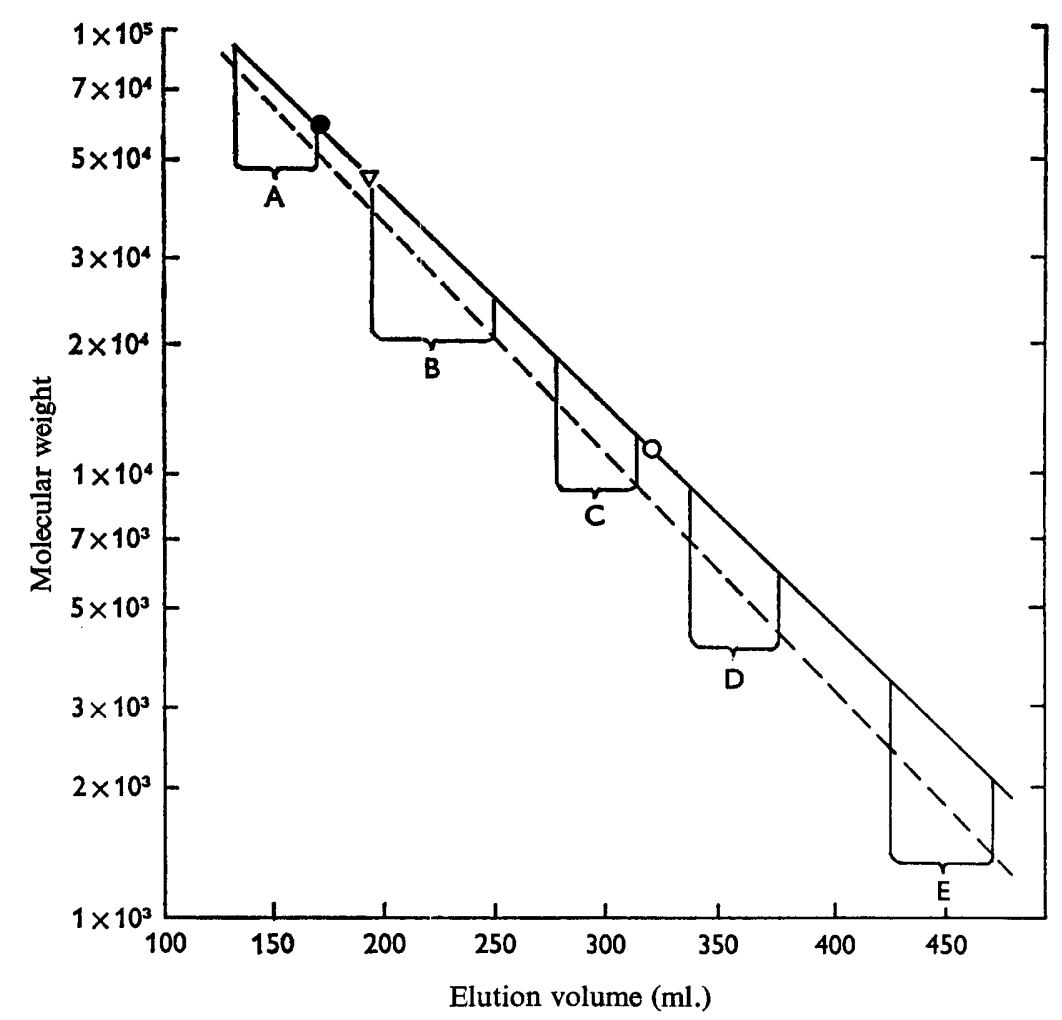

Fig. 2. Estimation of molecular weight by calibration of G-75 column. -, From standards; - - , theoretical; $\bullet$, serum albumin; $\nabla$, peroxidase; $\mathrm{O}$, cytochrome $\mathrm{C}$.

The separation of CM cellulases from cultures grown in CM cellulose or cellulose powder medium resulted in three main peaks designated $\mathrm{A}, \mathrm{B}$ and $\mathrm{C}$ and two smaller peaks D and E (Fig. 3). The approximate molecular weights of these components estimated from the standard curve (Fig. 2) are A 75,000, B 32,000, C I6,000, D 6500 and $\mathrm{E} 2200$.

$K_{m}$ determinations of components $\mathrm{A}, \mathrm{B}$ and $\mathrm{C}$ gave values of $\mathrm{I} \cdot 33 \times \mathrm{IO}^{-5}$, $2.86 \times 10^{-5}$ and $3.33 \times 10^{-5}$ at $\mathrm{pH} 5.0$, respectively, i.e. A had the highest affinity and $\mathrm{C}$ the lowest affinity for its substrate (Fig. $4 a, b, c$ ). High concentrations of substrate inhibited the reaction. The molecular weight of CM cellulose used for these determinations was calculated as 2500 (Fig. 5). These three components all showed activity 
over a wide $\mathrm{pH}$ range (Fig. $6 a, b, c$ ); $\mathrm{A}$ and $\mathrm{B}$ had two maxima, $\mathrm{A}$ at $\mathrm{pH} 4.5$ and 7.5 and $\mathrm{B}$ at $\mathrm{pH} 5.0$ and above 8.0 , whereas $\mathrm{C}$ had a single maximum at $\mathrm{pH} 8.0$. There was no difference in the viscosity of the $\mathrm{CM}$ cellulose controls at any $\mathrm{pH}$ value used, either initially or after incubation.

Incubation of A, B and C materials (derived from cultures grown in cellulose medium) separately with CM cellulose over an extended period showed that the viscosity of all the mixtures was tending towards the same value (Fig. $7 a$ ). Component B caused the most rapid breakdown of substrate (Fig. $7 b$ ). Since its $K_{m}$ was intermediate between that of components $\mathrm{A}$ and $\mathrm{C}$ this indicated a greater proportion of the B component in these cultures. At the end of this incubation, paper chromatograms

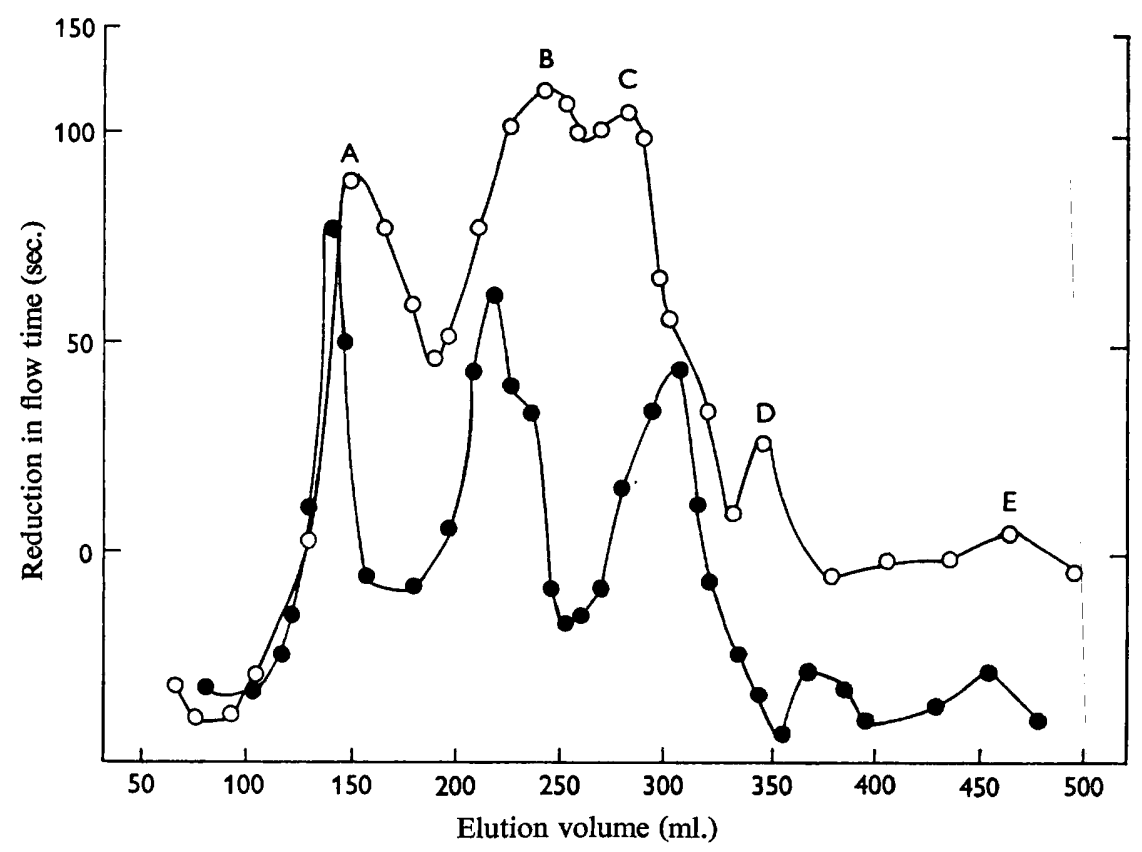

Fig. 3. Elution pattern of $\mathrm{CM}$ cellulases from culture filtrates. Cultures grown on cellulose powder; $O$, cultures grown on CM cellulose.

of the mixtures were run. These showed only the presence of cellobiose (authenticated by comparison with standard) and medium-length polymers (still at the origin). The ratio of cellobiose to medium-length polymers was much higher in the mixtures resulting from incubation with $\mathrm{C}$ than in those with either $\mathrm{A}$ or $\mathrm{B}$. There was no indication of short-chain polymers other than cellobiose. None of the three main peak components showed any cellobiase activity. The only glucose detected was a contaminant of the CM cellulose; this was shown by the chromatographic detection of glucose in CM cellulose in the same small quantities before enzymic hydrolysis as were found after reaction with the enzyme components.

There was a greatly increased (approximately 20-fold) degree of CM cellulase activity in the dead infected lucerne stem as compared with the healthy stem (Table I). The living tissue of infected plants had only a slightly (approximately three-fold) 
increased CM cellulase activity as compared with those of healthy plants. The dead root material was at this time extensively invaded by numerous saprophytic soil organisms and so a cellulase assay was not attempted.

(a)

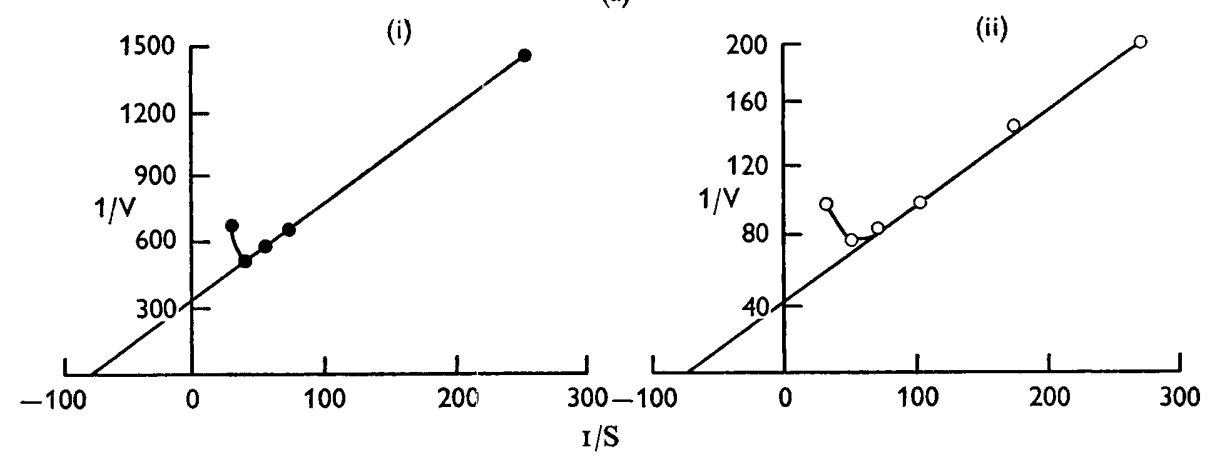

(b)

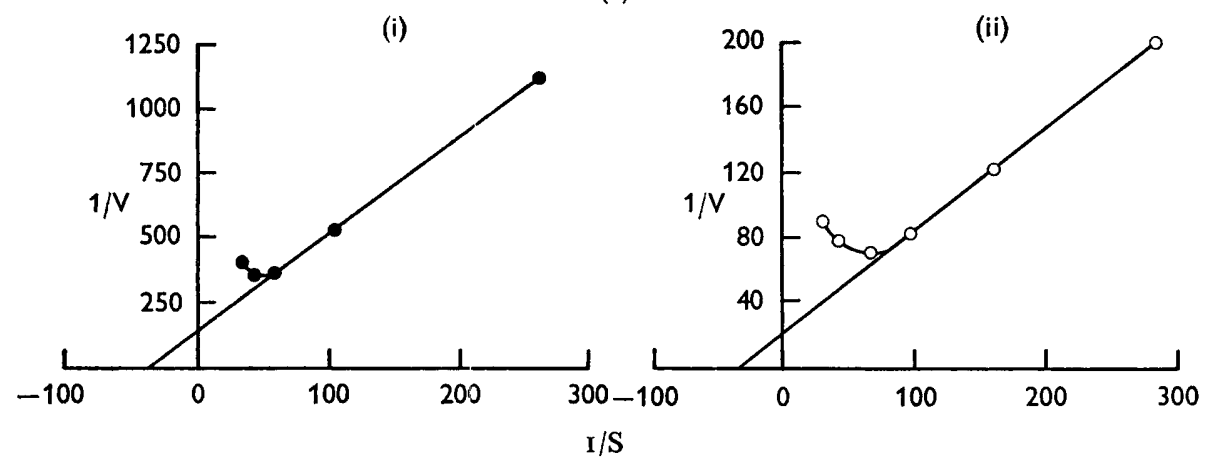

(c)

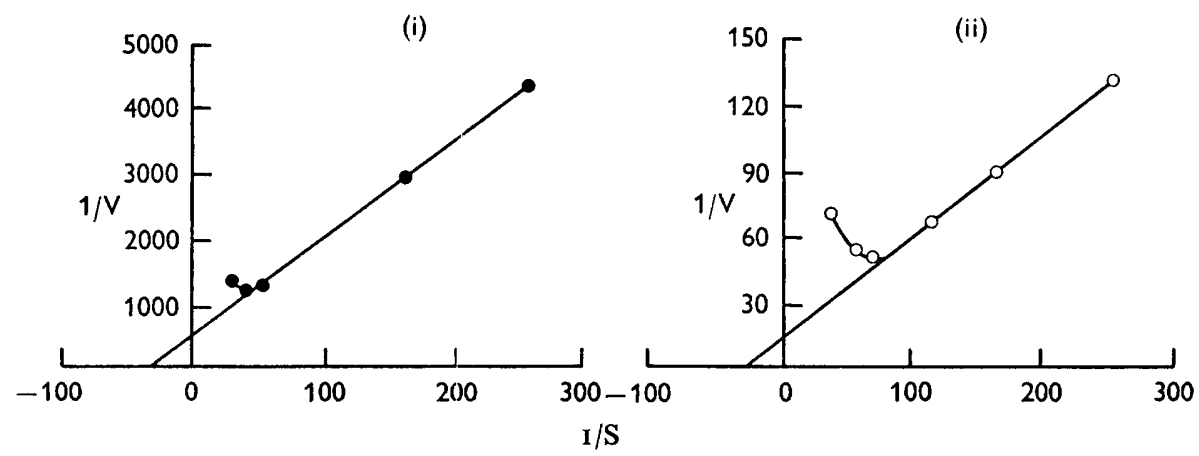

Fig. 4. Lineweaver-Burk reciprocal plots for $K_{m}$ determinations of enzyme peaks A (a), $\mathrm{B}(b)$ and $\mathrm{C}(\mathrm{c})$.

$\frac{\mathrm{I}}{\mathrm{S}}=\frac{\mathrm{I}}{\text { Substrate concentration }(\mathrm{mM})}$,

$\frac{\mathrm{I}}{\mathrm{V}}=\frac{\mathrm{I}}{\text { initial reaction velocity (decrease in CM cellulose equivs }(\mathrm{g} . / 100 \mathrm{ml} . / \mathrm{sec} .)}$ )

(i) Cultures grown on cellulose powder; (ii) cultures grown on $\mathrm{CM}$ cellulose. 


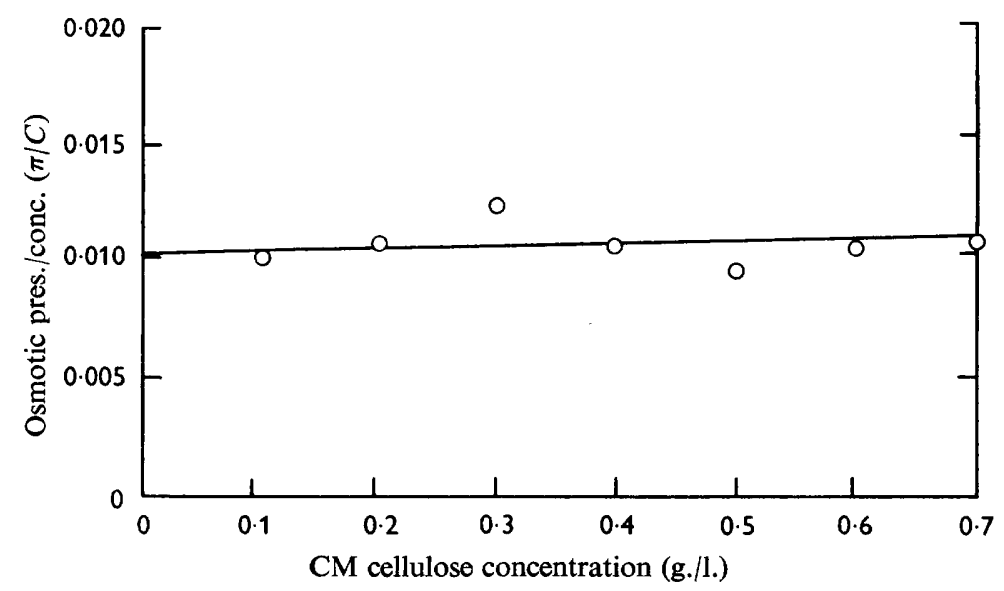

Fig. 5. Calculation of molecular weight of CM cellulose from osmotic pressure measurements. When the concentration tends to zero, $\pi / C=0.01025$. Average molecular weight $=\frac{R T}{\pi / C}=\frac{0.082 \times 307}{0.01025}=2456$.

Table I. Production of CM cellulase by Verticillium albo-atrum in lucerne tissue

$\begin{array}{lc}\text { Living stem } & \begin{array}{c}\text { Decrease in CM } \\ \text { collulose equivalents. } \\ \text { Assayed viscometri- } \\ \text { cally }\end{array} \\ \text { Lightected } & 0.010 \\ \text { Heavily infected old stem } & 0.030 \\ \text { Dead stem } & 0.025 \\ \text { Uninfected } & \\ \text { Infected } & 0.000 \\ \text { Living root } & 0.230 \\ \text { Uninfected } & \\ \text { Heavily infected old root } & 0.010 \\ \end{array}$

\section{DISCUSSION}

These experiments indicate that several distinct CM cellulases are produced extracellularly by Verticillium albo-atrum. The data also show that the components possess the same characteristics (molecular weight, Michaelis constant, activity/pH curve) whether induced by $\mathrm{CM}$ cellulose or cellulose powder as sole carbon source in the medium. The $K_{m}$ determinations were not ideal since the calculations assumed the breakdown of a highly viscous substrate to a product of viscosity similar to water though it is obvious that the medium-length polymers would have appreciable viscosity. However, since all the incubation mixtures progressed towards a similar viscosity, a valid comparison could be made between them and with other $K_{m}$ determinations similarly calculated (Mandels \& Reese, 1963). Although inhibition at high substrate concentrations is commonly encountered in hydrolytic enzyme systems it is doubtful whether a similar restricting mechanism was operating here, since we used a relatively low maximum substrate concentration. Any such 
inhibition might have been due to an increase in the viscosity of the reaction mixture decreasing molecular movement and hence availability of substrate to enzyme. The double $\mathrm{pH}$ optima obtained with components $\mathrm{A}$ and $\mathrm{B}$ were unexpected, since accord-
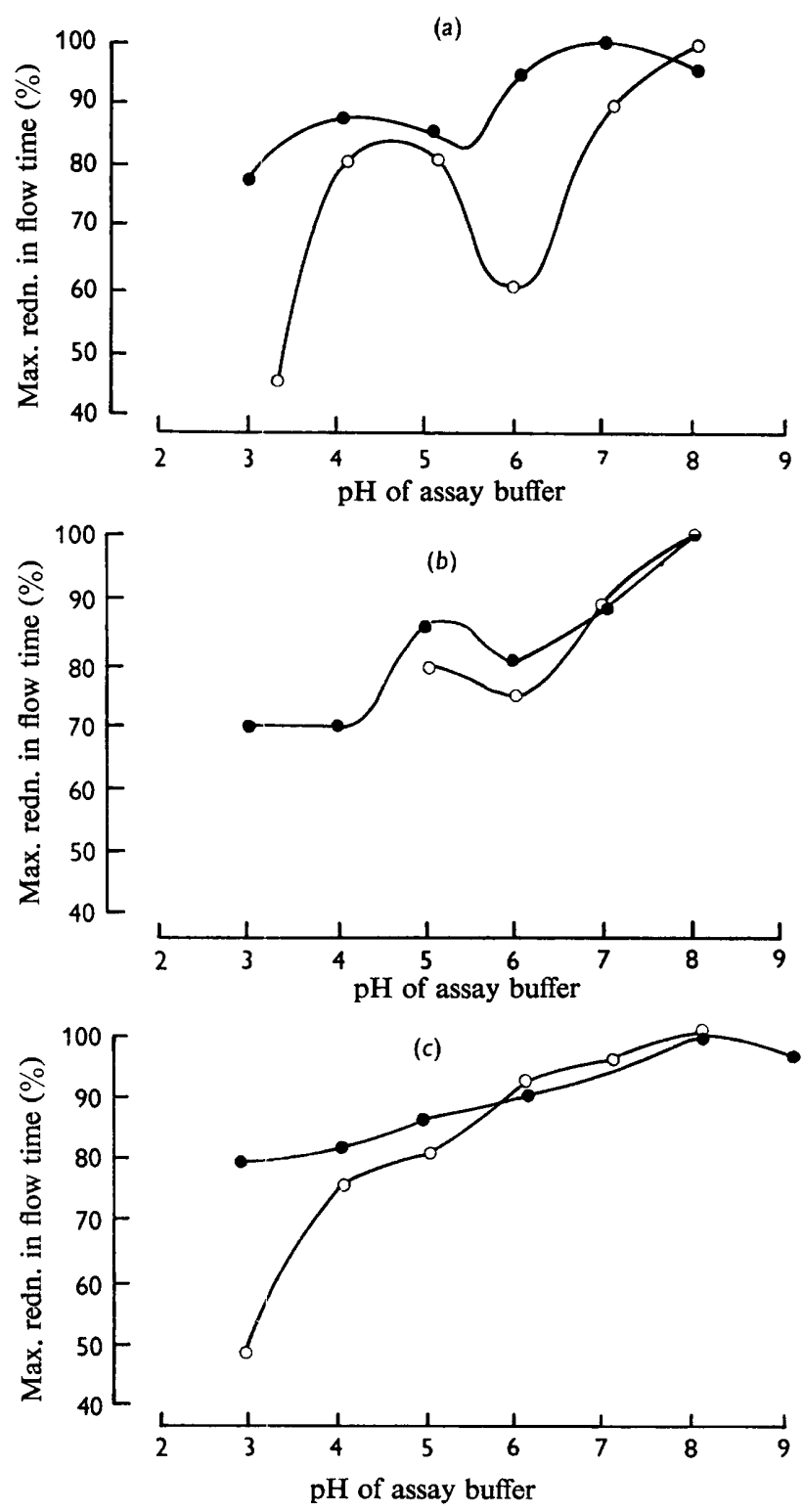

Fig. 6. $\mathrm{pH} /$ activity range of $\mathrm{CM}$ cellulase peaks $\mathrm{A}(a), \mathrm{B}(b)$ and $\mathrm{C}(c)$. $\bullet$, Culture grown on cellulose powder; $O$, culture grown on $\mathrm{CM}$ cellulose.

ing to Mandels \& Reese (1965) most cellulases have a single optimum between $\mathrm{pH}$ 4.5 and 5.5 . The double optima may indicate that the enzyme enters two active states, or alternatively that the presence of two enzymes of similar molecular weight which we had failed to separate. 
Of the five enzyme components separated, only B (MW 32,000) and D (MW 6500) can be correlated with any of those found by Selby \& Maitland (1965) in Myrothecium verrucaria cultures. The high molecular weights of components $\mathrm{C}, \mathrm{B}$ and particularly of A suggest that their action is largely restricted to exposed surfaces and loose chain ends, since molecules of this size would have difficulty in penetrating naturally occurring cellulose in the plant cell wall. Because of the difficulties inherent in investigating the initial steps of cellulose degradation no attempt was made to
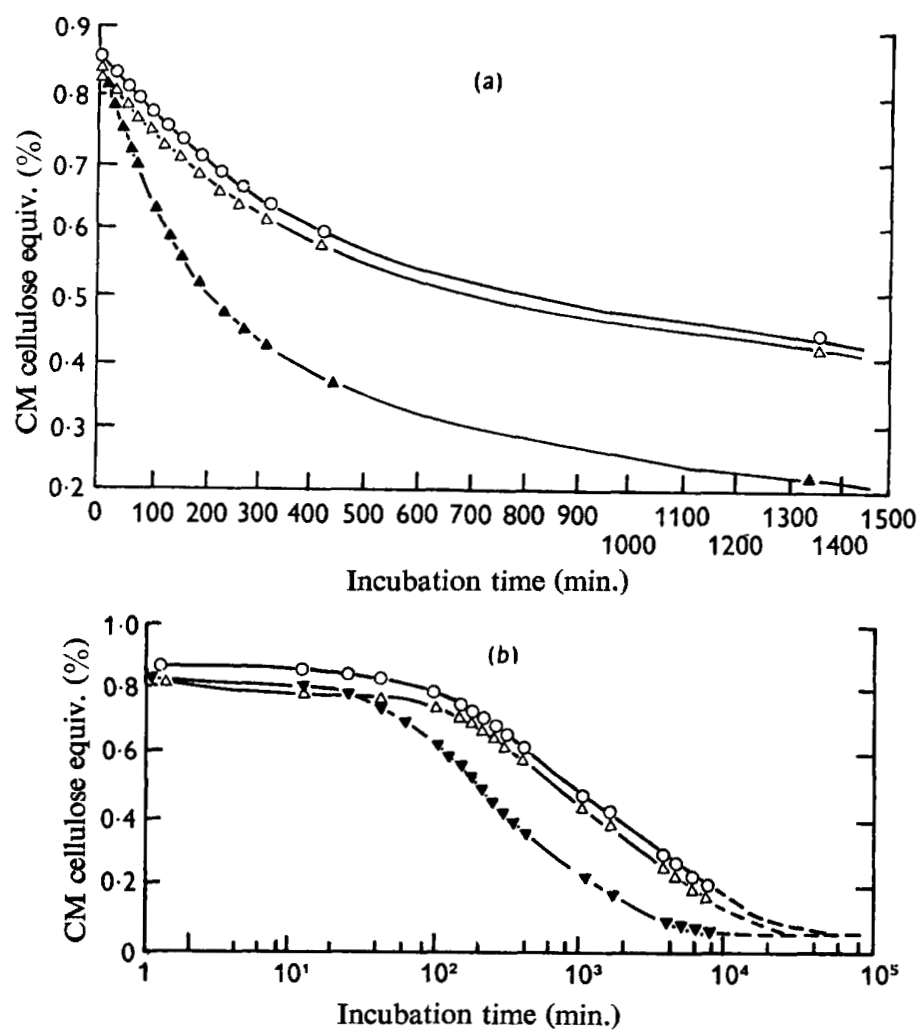

Fig. 7. Viscosity of $\mathrm{CM}$ cellulose plotted against time during incubation with enzyme peaks A, B and C.

(a) On a linear scale for about I day, O, Enzyme peak A; $\Delta$, enzyme peak B; $\Delta$, enzyme peak $\mathrm{C}$.

(b) On a logarithmic scale for about 7 days.

establish whether a CI component was produced by Verticillium albo-atrum. However, Selby \& Maitland (1967) showed that CM cellulases have no detectable effect alone on natural forms of cellulose so the fact that $V$. albo-atrum can utilize these as sole carbon source is circumstantial evidence for the presence of a $\mathrm{C}_{\mathrm{I}}$ component. No cellobiase activity was associated with any of the peak components and cellobiose was identified in the CM cellulose incubation mixtures and in harvested culture fluids containing cellulose powder as sole carbon source. This strongly suggests that cellobiose is the end product of cellulose breakdown by $V$. albo-atrum and is presumably taken up in this form by the hyphae. 
The simplest hypothesis to explain the different ratio of $\mathrm{CM}$ cellulose products shown in the three main peak components is that component $\mathrm{C}$ removes a cellobiose unit from the chain when it cleaves $\beta_{\mathrm{I}-4}$ linkages, whereas components $\mathrm{A}$ and $\mathrm{B}$ hydrolyse the linkage without removing a cellobiose unit (unless it is at the end of a chain). The degree of substitution controls the hydrolysis of cellulose by cellulases, the enzyme not attacking substituted glucose units (Mandels \& Reese, I965). In the present case the CM cellulose was substituted at 0.45 to 0.55 carboxymethyl groups per glucose unit (i.e. an average of one substituent group per two glucose units). It is likely that in some parts of the chain there would be two adjacent substituted glucose units and in other parts one substituent group per three or four glucose units. This would explain why all the CM cellulose was not hydrolysed to cellobiose and yet some cellobiose was produced.

The high values for CM cellulase in the dead infected stem, compared to living infected stem and healthy stem, indicate that the enzyme was only produced in large quantities after the death of the host tissue. This almost complete repression throughout the parasitic phase can be explained by an inhibition of enzyme production by sugars such as glucose and sucrose, as shown in in vitro studies by Talboys (1958) and by D. P. Gupta (personal communication). We cannot at this stage rule out the possibility that $\mathrm{CM}$ cellulases might be produced in minute amounts by fine penetration hyphae before and during passage through the host cell walls, although we have not yet successfully designed a technique to detect this. The activity detected in dead and dying tissue is of obvious importance to the pathogen. It enables an otherwise poorly competitive saprophyte (Heale \& Isaac, 1963) to utilize at least part of the cellulose fraction of the host (after the more easily assimilable sugars are exhausted) before general saprophytic invasion occurs. The darkly pigmented resting mycelium characteristic of Verticillium albo-atrum is formed during this latter stage of the disease and is of some importance in the survival of the fungus in the soil.

We wish to acknowledge, with thanks, grants from the Science Research Council to P. W. and from the Nuffield Foundation to J. M. C.

\section{REFERENCES}

BACon, J. S. D. \& BelL, D. J. (1948). Fructose and glucose in the blood of the foetal sheep. Biochem. J. 42, 397.

Bacon, J. S. D. \& Edelman, J. (I95I). The carbohydrates of the Jerusalem artichoke and other compositae. Biochem. J. 48, I I4.

B.D.H. Publication (1965). Ion Exchange Resins. London: British Drug Houses Ltd. 5th ed.

Heale, J. B. \& IsaAC, I. (1963). Wilt of lucerne caused by species of Verticillium. Ann. appl. Biol. 52, 439.

MANDELS, M. \& REESE, E. T. (1963). Inhibition of cellulases and $\beta$-glucosidases. In Enzymic Hydrolysis of Cellulose and Related Materials. Ed. E. T. Reese. Oxford, London, New York, Paris: Pergamon Press.

Mandels, M. \& Reese, E. T. (1965). Inhibition of cellulases. A. Rev. Phytopath. 3, 85.

NeLson, N. (1944). A photometric adaptation of the Somogyi method for determination of glucose. J. biol. Chem. 153, 275.

Pettesson, G. (1968). Studies on cellulolytic enzymes. III. Isolation of cellulase from Penicillium notatum. Archs. Biochem. Biophys. 123, 307.

Polis, B. D. \& ShmukLer, H. W. (I953). Crystalline lactoperoxidase. J. biol. Chem. $201,476$. 
Selby, K. \& MAITLAND, C. C. (1965). The fractionation of Myrothecium verrucaria cellulase. Biochem. $J .94,578$.

Selby, K. \& Maitland, C. C. (1967). The cellulase of Trichoderma viride. Biochem. J. 104, 716.

SomoGYI, M. (1952). Note on sugar determination. J. biol. Chem. 195, 19.

Stoddart, J. L. \& Carr, A. J. H. (I966). Properties of wilt-toxins produced by Verticillium alboatrum. Ann. appl. Biol. 58, 8I.

TALBoys, P. W. (1958). Degradation of cellulose by Verticillium albo-atrum. Trans. Br. mycol. Soc. 4I, 247.

WhITAKER, J. R. (1963). Determination of molecular weights of proteins by gel filtration on Sephadex. Analyt. Chem. 35, 1950. 